\title{
Sår, der heler langsomt
}

Indtryk fra debatarrangementet den 30. januar 2007 om det tyske mindretal og retsopgøret efter maj 1945

\author{
af REDAKTIONEN
}

Besættelsestiden og retsopgøret efter maj 1945 er ikke et afsluttet kapitel i grænselandet. Den dag i dag er erindringen om disse år levende i befolkningen i Sønderjylland, både i den danske flertalsbefolkning og det tyske mindretal. Og selvom forholdet mellem dansk og tysk i dag er præget af afspænding og samarbejde, er opfattelsen af historien forskellig.

Sådan må det nødvendigvis være. Forsoning mellem to parter, der engang var på kollisionskurs, forudsætter ikke nødvendigvis en omfortolkning af historien, således at alle kan skrive under på den. Men forsoningen forudsætter, at parterne hver især forsøger at sætte sig ind $\mathrm{i}$ den andens syn på tingene - $\mathrm{i}$ dette tilfælde på de ulykkelige begivenheder i grænselandet i tiden mellem 1933 og 1945 og i det opgør, der fulgte efter.

Dette var baggrunden for et debatarrangement, som Historisk Samfund for Sønderjylland og det tyske mindretals paraplyorganisation Bund Deutscher Nordschleswiger (BDN) afholdt tirsdag eftermiddag den 30. januar 2007 i Riddersalen på Sønderborg Slot.

Den konkrete anledning til arrangementet leverede undervisningsminister Bertel Haarder på det danske årsmøde i Flensborg den 11. juni 2006, hvor han udtalte, at der i en kort periode umiddelbart efter den tyske kapitulation blev begået uret mod medlemmer af det tyske mindretal i Sønderjylland. Undervisningsministeren, der selv havde oplevet befrielsen i sin barndom i Rønshoved, udtalte, at "danskerne i dag skal være store nok til at indrømme, at retsopgøret straffede for mange og for hårdt«. (Flensborg Avis 12. 06. 2006).

Undervisningsministerens udtalelser blev modtaget med tilfredshed i det tyske mindretal. Forhenværende BDN-hovedstyrelsesmedlem Jens Harrebye fra Haderslev udtalte til Der Nordschleswiger (13. 06. 2006), at det var "fantastisk «, at udtalelserne var faldet netop på 


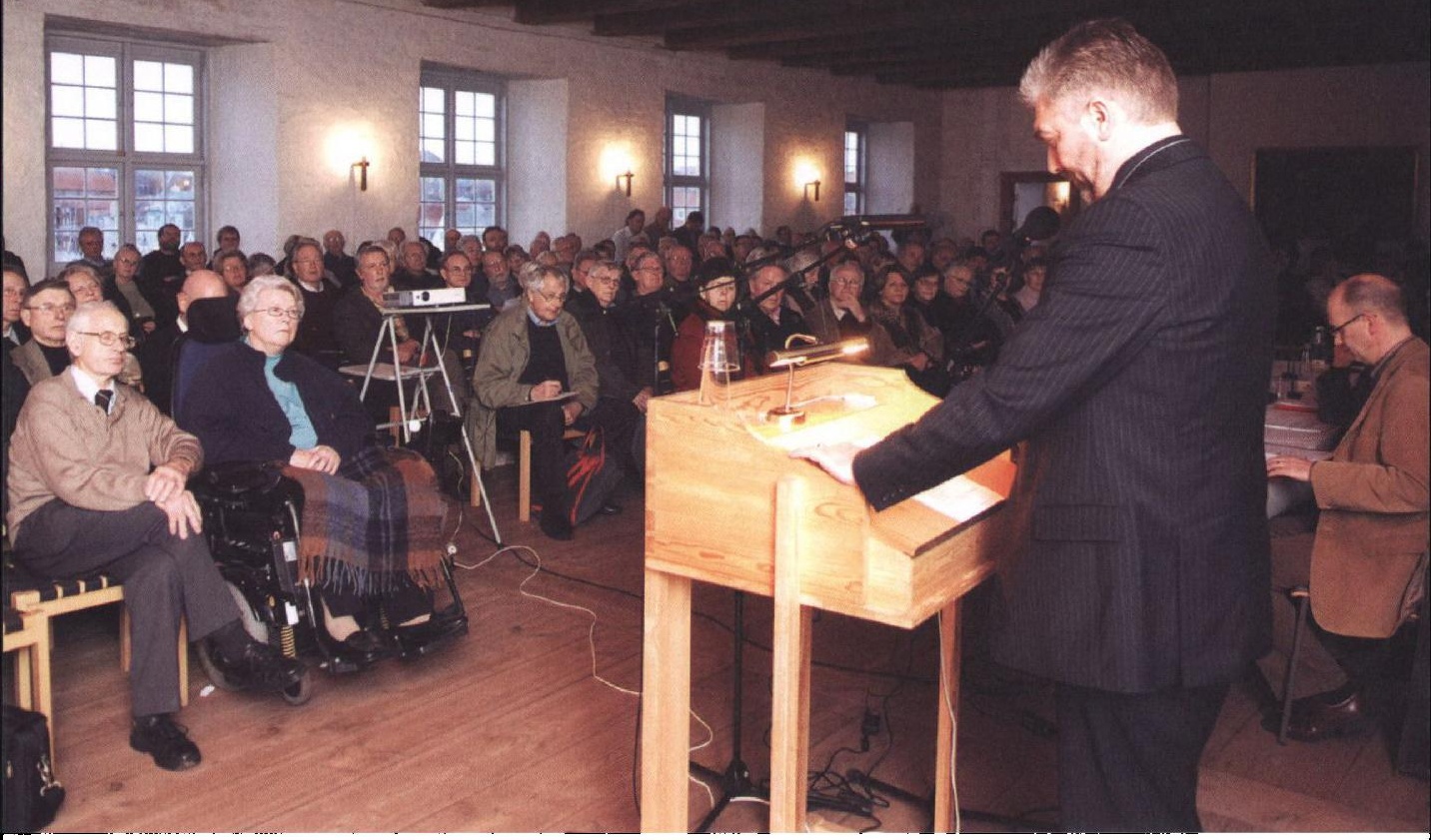

Der var mødt cirka 250 tilhorere op til debatmødet om retsopgøret med det tyske mindretal efter maj 1945. Her byder formanden for Bund Deutscher Nordschlestriger, Hinrich Jürgensen, velkommen $i$ Riddersalen på Sønderborg Slot. På forreste stolerække umiddelbart foran taleren ses forhenvarende BDN-formand Gerhard Schmidt og hustru. Foto: Povl Klavsen, Flensborg Avis.

det danske årsmøde i Sydslesvig. "Det har bestemt ikke lydt godt i ørerne på de danske tilhørere, " udtalte han og konkluderede, at udtalelserne var en stor tilfredsstillelse for det tyske mindretal. $\mathrm{Og}$ Andreas Jochens, der som 16-årig meldte sig til tysk krigstjeneste, udtalte: "Det var på høje tid, at det blev sagt offentligt! « Jochens blev straffet under retsopgøret, og "det var bittert!, " udtalte han. "Jeg er ikke landsforræder. Jeg har ikke kæmpet imod Danmark. Og jeg har ventet længe på en undskyldning, " udtalte Andreas Jochens til Der Nordschleswiger (16. 06. 2006).

Der Nordschleswigers lederskribent den 13. juni 2006 gav også udtryk for glæde over udtalelserne. Avisen mindede dog om, at de ikke måtte misbruges som en frifindelse af mindretallet for dets nationalsocialistiske kurs fra 1933 til 1945. Ifølge avisen var det Bertel Haarders hensigt at rette fokus mod de "ikke så få sønderjyske enkeltsager, hvor der blev begået uret«. Bertel Haarder ville fjerne »den tunge kollektive skyld «, som hviler over mindretallet, og det skulle han have tak og anerkendelse for, skrev Der Nordschleswiger, som til sidst 
stillede det sporgsmål, om udtalelserne skulle ses som ministerens private holdning, og i så fald hvorfor han havde tiet så længe?

Nogle måneder efter årsmødet $\mathrm{i}$ Flensborg tog Bertel Haarder imod en delegation fra det tyske mindretal bestående af BDN's daværende formand Hans Heinrich Hansen, chefredaktør for Der Nordschleswiger, Siegfried Matlok, og pastor emeritus Günter Weitling. Her var der enighed om, at der var flere spørgsmål vedrørende det tyske mindretals forhold under og efter besættelsen, som krævede en grundig historisk undersøgelse. I den forbindelse understregede Günter Weitling, at det, der var brug for, var en undersøgelse af de enkelte mindretalsmedlemmers forhold - ikke en generel revision af retsopgøret.

Det var som følge af disse begivenheder, at Historisk Samfund for Sønderjylland sammen med BDN tog initiativ til debatarrangementet på Senderborg Slot den 30. januar 2007. Flere end 250 interesserede personer dukkede op, heraf en stor del fra det tyske mindretal.

Efter velkomster af Historisk Samfunds formand Hans Schultz Hansen og BDN's nye formand, Hinrich Jürgensen, gav museumsinspektør ved Frøslevlejrens Museum, Henrik Skov Kristensen, en historisk redegørelse for mindretallets forhold under retsopgøret og under interneringen og fængslingen i Fårhuslejren. Et referat af denne redegørelse ville sprænge rammen for denne artikel. Derfor henvises der til Henrik Skov Kristensens artikler i henholdsvis Sønderjylland under krig og besættelse 1940-1945 (Historisk Samfund for Sønderjylland 2004) og »Det tyske mindretal og Fårhuslejren. Retsopgøret på museum.« I tidsskriftet Historie 2005,1, s. 54-110 (2005).

Henrik Skov Kristensens indlæg mundede ud i en samlet vurdering af mindretallets forhold under retsopgøret. Dernæst gav mindretallets historiker og forhenværende leder af det tyske museum i Sønderborg, pastor emeritus Günter Weitling, samt forskningsleder ved Statens Arkiver Hans Schultz Hansen og chefredaktør Siegfried Matlok deres vurderinger, hvorefter ordet blev givet til tilhørerne, som fik mulighed for at stille spørgsmål og bidrage med personlige betragtninger.

I det følgende fremhæves nogle af de emner, der blev behandlet.

\section{Opgørets legitimitet}

Et af de centrale spørgsmål, som gik igen i alle indlæg, var spørgsmålet om, hvorvidt opgøret overordnet set var legitimt eller rimeligt. På dette punkt var der ikke enighed blandt paneldeltagerne. Henrik 
Skov Kristensen gav bolden op i sit indlæg. Han understregede, at mindretallet blev dømt efter de samme love som andre danske statsborgere. Hver enkelt fik sin sag prøvet ved en domstol, og man straffede udelukkende handlinger og ikke holdninger. Og med udblik til resten af verden pointerede han: "Mindretallet blev ikke kollektivt dømt, blev ikke fordrevet og blev ikke efterstræbt på livet, sådan som det skete for andre tyske mindretal i Europa.«

Henrik Skov Kristensen sagde, at der fra hjemmetysk side især har været anket over, at de tilbageholdte ikke blev stillet for en dommer indenfor 24 timer. Han forklarede: »De omfattende interneringer over hele landet medførte, at personer blev frihedsberøvet, uden at grundlovens krav om fremstilling for en dommer inden for 24 timer kunne overholdes. " Først efter at det danske politi den 13. maj 1945 var trådt i funktion, begyndte anholdelserne efter almindelige regler. Gradvist blev de internerede overgivet fra modstandsbevægelsens varetægt til politiet med henblik på fremstilling for en dommer inden 24 timer, sagde Henrik Skov Kristensen. I Fårhuslejren betød det, at lejren blev delt op i to afdelinger: én for internerede og én for arrestanter. Fangebarak efter fangebarak blev indhegnet og underlagt det danske fængselsvæsen i takt med, at internerede skiftede status til arrestanter: »De sønderjyske politikredse og byretter arbejdede på højtryk inde i selve Fårhuslejren, og dagligt blev mellem 35 og 50 internerede fremstillet for en dommer, « fortalte Henrik Skov Kristensen.

Han understregede, at der ind i mellem forekom voldelige overgreb mod de internerede i Fårhuslejrens første måneder, selv om det ifølge lejrreglementet var strengt forbudt. Han fortsatte: "Men først og fremmest var lejren gennemsyret af kadaverdisciplin. Og tonen over for de indsatte har sikkert ofte været både ydmygende og hård.«

Henrik Skov Kristensen indrømmede, at det naturligvis altid er betænkeligt, når man - som det var tilfældet med Straffelovstillægget anvender lovgivning med tilbagevirkende kraft. Men når mindretallet åbent hvervede for at få danske statsborgere til at gå i tysk krigstjeneste, og når mindretallets unge mænd meldte sig til Waffen SS, så "lå dette helt klart uden for rammerne af det nationalt tilladelige, « vurderede han. "Ikke mindst mindretallet var klar over, at den tyske 'fredsbesættelse' af Danmark var alt andet end fredelig: Der var deciderede kampe i Sønderjylland den 9. april, og den danske konge og regering tog ganske vist imod det tyske tilbud om en 'fredsbesættelse', men det skete under udtrykkelig protest. Dansk suverænitet og uafhæn- 
gighed var med en tysk besættelsesstyrke i landet selvfølgelig en ren fiktion. Og meget fă i samtiden var i tvivl om, at Danmark befandt sig i en tvangssituation, " sagde Henrik Skov Kristensen.

Mindretallets ledelse var klar over, at den overskred en vigtig grænse, da den hvervede unge mænd til den hær, der holdt Danmark besat. Og den vidste, at den ville komme til at betale en høj pris efter et tysk nederlag: »Så stærk var den nationale kløft mod krigens slutning, at mange i mindretallet anså det for overordentlig sandsynligt, at de slet ikke kunne blive i hjemstavnen efter et tysk nederlag," sagde Henrik Skov Kristensen og fortsatte: »Lovene med tilbagevirkende kraft skal anskues i en politisk kontekst: De var udtryk for den danske befolknings retsfølelse og ikke for ideelle retsprincipper. « Det var den danske flertalsbefolknings opfattelse af det tyske mindretals illoyale adfærd og angreb på grænsen igennem 12 år fra 1933-1945, herunder fem års ubetinget solidaritet med besættelsesmagten, der nu fik udløsning i et efter omstændighederne behersket retsopgør. Og Henrik Skov Kristensen understregede, at det indtil juni 1941 faktisk var ulovligt at hverve til tysk krigstjeneste på dansk statsområde. Det var derimod ikke ulovligt at lade sig hverve.

Også Günter Weitling pegede på, at retsopgøret først og fremmest var politisk motiveret. Der var i den danske befolkning et krav om et opgør, og hvis ikke dette opgør var kommet, kunne man have risikeret, at befolkningen havde grebet til selvtægt. Men i modsætning til Henrik Skov Kristensens pointe om, at mindretallets unge mænd vidste, at de overskred en farlig grænse, da de meldte sig til fronten, havde Günter Weitling mere forståelse for de frivillige. Han mente, at det var rimeligt, at mindretallet efter 1945 havde protesteret over, at de unge mænd, som havde meldt sig til tysk krigstjeneste, blev kriminaliseret. De havde handlet i den tro, at det var i overensstemmelse med loven, sagde Günter Weitling.

Det var også Siegfried Matloks vurdering. Han henviste til statsminister Anders Fogh Rasmussens skarpe kritik af den danske samarbejdspolitik under besættelsen. Kritikken i sig selv var Siegfried Matlok ikke enig i, men hvis man var enig i statsministerens fordømmelse af samarbejdspolitikken, "så har det tyske mindretal jo netop ret i sin påstand om, at mindretallet ikke kunne tolke den danske politiks holdning over det den tyske besættelsesmagt anderledes, end den blev udtrykt af den danske regering, og at de enkelte medlemmer derfor blev straffet på et forkert moralsk grundlag." 
Siegfried Matlok hæftede sig også ved den måde, som nogle dommere havde tolket Straffelovstillægget på. Det var sandt, at justitsministeriet havde henstillet til de sønderjyske dommere, at man i strafudmålingen skulle tage hensyn til mindretallets særlige loyalitetsforhold, men enkelte myndigheder havde bevidst set bort fra denne instruks, sagde Siegfried Matlok: »For eksempel har den daværende statsadvokat og chefanklager Dines Kirk i de første domme, der blev afsagt, ignoreret den instruks, han fik fra den danske regering om at tilgodese, at der også lå nogle ideelle motiver $\mathbf{i}$ at tilhøre det tyske mindretal, motiver, som skulle være strafmildnende."

Siegfried Matlok pegede i øvrigt på det særlige forhold, at mange af de mindre "alvorlige" sager, der vedrørte menige medlemmer af mindretallet, nåede frem til domsafsigelse, mens folkestemningens pres på domstolene endnu var stort, hvorimod ledernes mere komplicerede sager først blev afsluttet, da stemningen havde lagt sig noget. Det havde ført til en skævhed, understregede Siegfried Matlok: »Om retsopgøret vil jeg ganske kort sige, at de små fisk blev hårdt dømt, mens de store fisk, som kom for retten, da folkestemningen havde lagt sig en smule, gik rimeligt frit."

På mindretallets side var der altså enighed om, at retsopgøret de jure og de facto havde ramt mange mindretalsmedlemmer urimeligt hårdt. En tilsvarende enighed fandtes ikke blandt panelets to danske medlemmer. I forhold til Henrik Skov Kristensen var Hans Schultz Hansen lidt mere imødekommende over for mindretallets kritik at retsopgøret.

Hans Schultz Hansen resumerede nogle af de punkter, hvor retsopgøret kom i konflikt med de retsstatslige normer. For det første var der interneringerne. Her var for mange blevet taget med, og forløbet havde ofte været stærkt $y d m y g e n d e$ for de internerede - $i$ værste fald var der blevet brugt vold. Ansvaret herfor tilfaldt modstandsbevægelsen, som stod for interneringerne, og de sønderjyder, der så på og kom med tilråb og forhånelser, sagde Hans Schultz Hansen. For det andet var Grundlovens krav om at stille anholdte for en dommer inden for 24 timer blevet klart overtrådt, hvilket de berørte oplevede som en krænkelse, selvom det måtte være indlysende, at det var praktisk umuligt at stille alle de anklagede for en dommer straks efter Befrielsen, understregede Hans Schultz Hansen. Til forklaring tjente, at retsstatens normale ordensmagt var sat ud af spillet ved besættelsesmagtens internering af det danske politi den 19. september 1944. Han pegede også på det problematiske forhold, at der blev lovgivet 
med tilbagevirkende kraft helt tilbage til den 9. april 1940. Dette fik først og fremmest konsekvenser for de frontfrivillige. Ved at lade sig hverve havde de ikke forbrudt sig mod gældende dansk lov, men blev alligevel straffet efter 1945: "Her står vi uden tvivl ved det punkt, hvor retsopgøret med det tyske mindretal er vanskeligst at forsvare, " indrømmede Hans Schultz Hansen.

Imidlertid fandt han det ikke tilstrækkeligt at anskue mindretallets adfærd under krigen og det efterfølgende retsopgør udelukkende under en juridisk synsvinkel. En bedømmelse måtte bl.a. også inddrage perspektivet: kampen mellem nazisme og demokrati. Det var dokumenteret til overflod, at Nazityskland var et af de værste forbryderregimer i den menneskelige historie: »I det lys var demokratiernes kamp et forsvar for fred, frihed og civilisation. I grænselandet var det den sønderjyske modstandsbevægelse, som var at finde på den rigtige side i den kamp, og for den var retsopgøret - med kravet om "udrensning til tops og til bunds « - at føre kampen til ende. Mindretallet solidariserede sig derimod helt gennemgående med den forkerte side. De frontfrivillige bidrog med deres indsats i Waffen-SS til at sikre, at de nazistiske forbrydelser mod menneskeheden kunne fortsætte bag fronten «. Derfor var det ifølge Hans Schultz Hansen naturligt, om den enkelte efter krigen stillede sig selv spørgsmålet: "Hvad har jeg dog været med til?«.

Under spørgerunden senere på aftenen stillede formanden for den hjemmetyske soldaterforening, Andreas Fleischer, Aabenraa, det spørgsmål, hvorfor de østfrontfrivillige var blevet straffet, mens de danske Finlandsfrivillige var gået fri. Begge grupper havde jo meldt sig til kampen mod kommunismen. Hvad var forskellen?

Hans Schultz Hansen svarede, at forskellen bestod i, at de Finlandsfrivillige havde kæmpet for at støtte et fredeligt lille land, som blev overfaldet af en totalitær stormagt uden nogen folkeretslig gyldig begrundelse. Direkte henvendt til Andreas Fleischer sagde han dernæst: "Du og andre østfrontfrivillige indgik i en angrebskrig, hvor det ene totalitære styre angreb det andet ud fra en ideologisk forestilling om, at borgerne i Østeuropa og Sovjetunionen var mindreværdige, var racemæssigt underlegne. Det var en kamp, som blandt andet i kraft af den såkaldte Kommissarbefehl [til at likvidere politiske kommissærer blandt de sovjetiske krigsfanger, red.] tilsidesatte almindeligt galdende regler for krigsførelse. « Dertil kom naturligvis den ikke uvæsentlige detalje, at Finland ikke holdt Danmark besat i vinteren 1939-1940. 
Den vurdering blev i øvrigt støttet fra salen, nemlig fra Henning Skjoldager Olsen. Han sagde: »Min farfar var med i Finland $i$ vinterkrigen og kom hjem. Min far, som ikke tilhørte mindretallet, meldte sig frivilligt til SS og faldt i Estland. For mig er der utrolig stor forskel på de to måder at gå i krig på. Jeg har aldrig kendt min far, men jeg har ikke de store tanker om ham, for jeg mener, at han har mærket den modvilje der var, da han i foråret 1943 meldte sig til SS."

Selvom der ikke var enighed i panelet, så var afstraffelsen af de frontfrivillige med tilbagevirkende kraft trods alt det punkt, hvor paneldeltagernes synspunkter kom tættest på hinanden.

\section{Konfiskationer}

Et andet vigtigt aspekt af retsopgøret i Sonderjylland var konfiskationen af tysk ejendom. Dette emne kom ingen af paneldeltagerne ind på i deres indlæg, og derfor blev det taget op af en af tilhørerne, Inger Harms, der spurgte til de nærmere omstændigheder omkring konfiskationerne, herunder om de berørte fik erstatning for deres tabte ejendom.

Hans Schultz Hansen forklarede, at de gårde, som blev beslaglagt, var gårde, som var ejet af det såkaldte Höfeverwaltungsgesellschaft, en særlig afdeling af Kreditanstalt Vogelgesang, som var oprettet i 1926. Selskabet havde med tyske statsmidler i slutningen af 1920 'erne og i begyndelsen af 1930'erne overtaget en række ejendomme, der under krisen havde måttet opgives af medlemmer af mindretallet. Det skete for at forhindre, at ejendommene kom ud i fri handel og derved risikerede at blive købt af dansksindede. Ofte var det de samme personer, der drev gårdene videre, nu som forpagtere, forklarede Hans Schultz Hansen. Gårdene var altså at regne for tysk statsejendom og skulle som sådan konfiskeres. "Så man kan ikke sige, at medlemmer af mindretallet har fået konfiskeret deres ejendom som en del af retsopgøret, « sagde Hans Schultz Hansen.

Hertil skød Siegfried Matlok ind, at grev Scheel-Plessen af Holsten havde fået beslaglagt sit gods i Nørrejylland til trods for, at familien under besættelsen havde været i kontakt med den danske modstandsbevægelse og havde gemt våben for den danske modstandsbevægelse. Siegfried Matlok konkluderede "Og alligevel har man indtil i dag ikke kunnet mande sig op til at sige undskyld eller også give noget symbolsk tilbage. Det kalder jeg uret.« 
Günter Weitling nævnte, at der også havde været andre konfiskationer, nemlig dem, der ramte lærerne. Lærerne blev dømt temmelig hårdt efter en særdomstol, der blev oprettet for tjenestemænd og lærere. De blev dømt ikke efter gerninger, men efter holdninger. De blev dømt, hvis de f.eks. havde været medlemmer af en forening, der var tilknyttet NSDAP, forklarede Günter Weitling.

Mange af de dømte lærere havde haft en absolut kritisabel indstilling til lærergerningen, erindrede Günter Weitling: "Jeg har selv oplevet lærere, som troede, at de befandt sig på en SK-kaserne og ikke i en underskole, i fuld uniform og Hitler-hilsen om morgenen, " sagde han og fortsatte: "Men jeg må også sige, at der også var nogle lærere af ganske modsat observans. Privatskolelærerne, der ofte var tyske statsborgere, blev for størstedelens vedkommende udvist, og deres private ejendom blev konfiskeret, også hvis de havde private huse, og jeg er da ikke vidende om, at de har fået nogen erstatning siden hen. Også de kirkelige forhold bør nævnes. Alle præstegårde under den tyske frimenighed, Nordschleswigsche Gemeinde, blev konfiskeret. Tre blev givet tilbage. Men det var fordi der var tilflydt frimenigheden penge fra clearingkontoen, så man kan sige, at det måske var rimeligt, at det skete."

Fra salen meldte historikeren Kirsten Lylloff sig med en bemærkning vedrørende konfiskationerne. Hun fortalte, at hun var ved at skrive en bog netop om konfiskationen af ejendomme efter krigen. Ifølge hendes oplysninger var hovedparten af de gårde, som blev konfiskeret, ejet af tyske statsborgere, altså ikke af medlemmer af mindretallet. Det var tyske borgere, som boede i Sønderjylland eller som boede syd for grænsen og havde jord nord for grænsen. Konfiskationen skete $i$ henhold til en lov, der blev vedtaget i 1946. Frem til 1957 blev en del af det konfiskerede gods givet tilbage, men for ejendommene gjaldt det, at de allerede var blevet solgt videre, forklarede Kirsten Lylloff.

En anden tilhører, Henrik Haase, berettede om sin far, der havde været advokat, og som efter maj 1945 havde repræsenteret to mindretalsmedlemmer, en bager og en barber, som havde faet deres forretninger konfiskeret. Sagen var den, at de efter genforeningen i 1920 ikke havde fået ændret statsborgerskab, og det ramte dem hårdt, forklarede Henrik Haase: »Pludselig blev deres forretninger konfiskeret. Og min far kunne ikke hjælpe dem.« 


\section{Det andet Tyskland}

Siegfried Matlok understregede i sit indlæg, at man fra dansk side havde haft en tendens til at se det tyske mindretals forhold under nazismen sort-hvidt. Der blev alt for ofte set bort fra de moderate og demokratisk indstillede kredse i mindretallet. Derfor glædede han sig over, at man for nylig havde fundet den forsvundne originale "Haderslebener Erklärung", der blev formuleret den 11. november 1943 af indflydelsesrige mænd i mindretallet. I denne erklæring blev der givet afkald på grænserevisionskravet og erklæret loyalitet mod den danske herbergstat.

Siegfried Matlok glædede sig over, at den politik, der var indeholdt i erklæringerne, trods alt havde sejret. Han pegede på, at BDN's tidligere formand, Gerhard Schmidt, i 1986 på mindretallets vegne havde taget medansvar for begivenhederne under nazismen. Dette medansvar havde efterfølgeren, Hans Heinrich Hansen, gentaget. Siegfried Matlok fortsatte: "Der kan ikke blive tale om et kollektivt ansvar eller en kollektiv skyld. Det må være et individuelt spørgsmål. Men der kan være tale om kollektiv skam over ugerninger og forbrydelser.«

Siegfried Matlok nævnte i øvrigt et eksempel på et mindretalsmedlem, som var blevet urimeligt mildt straffet på grund af sit tilhørsforhold til mindretallet, nemlig Anton Peter Callesen fra Rends, der havde været næstkommanderende i kz-lejren Laagberg ved Wolfsburg. Han meldte sig til Waffen SS i 1942 og blev kendt for sin ekstreme brutalitet over for fangerne i lejren. I maj $1945 \mathrm{blev}$ han arresteret og dømt til fire års fængsel. Da hans forbrydelser kom frem, måtte han i 1950 igen for retten. Ved Vestre Landsret blev han dømt til døden for forbrydelser mod menneskerettighederne. Alligevel blev dommen i slutningen 1950 ændret til livsvarigt fængsel. Han blev losladt allerede i 1951, forklarede Siegfried Matlok. Han forstatte: "Jeg spørger mig selv, hvordan det kan være muligt i forhold til, hvad andre har fået af domme? «

Siegfried Matlok kritiserede mindretallet for at have ventet for længe med at tage medansvar: »Tesen i mindretallet var: Det tyske mindretal er uskyldigt forfulgt, og har næsten ikke gjort noget! Jeg må sige, at det er en sandhed med modifikationer, " sagde Siegfried Matlok.

Siegfried Matlok pegede på, at det var nødvendigt at skelne imel- 


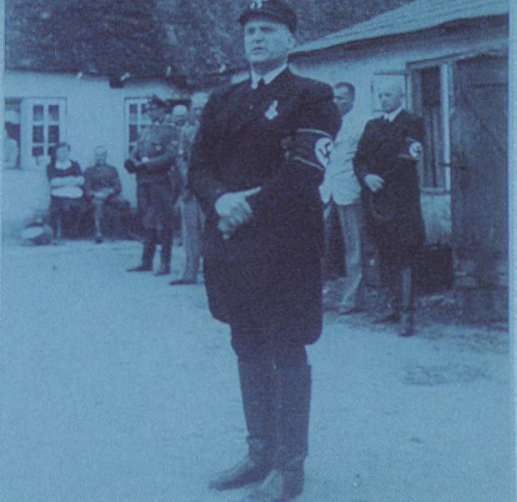

"Så stærk var den nationale kløft mod krigens slutning, at mange $i$ mindretallet anså det for overordentlig sandsynligt, at de slet ikke kunne blive i hiemstavnen efter et tysk nederlag," udtalte museumsinspektor Henrik Skov Kristensen $i$ sin vurdering af retsopgorets legitinitet. På larredet ses dyrlæge Jens Möller, lederen af mindretallets nazistiske parti NSDAP-N. Foto: Jesper Balleby, JydskeVestkysten.

lem det tyske mindretals politik fra 1940 til 29. august 1943, og så tiden derefter. Han lagde ikke skjul på, at politikken før august 1943 havde været forkert og forfærdelig. Men mindretallet havde reelt ikke haft mulighed for at foretage en kursændring - slet ikke efter august 1943, hvor der måske var størst grund til det. Han fortsatte med et eksempel: »Hvis den hjemmetyske soldat efter denne dato - den 29. august 1943 - havde nægtet at medvirke i tyske krigstjeneste, var han selvfølgelig blevet skudt med det samme som desertør. Hvis det tyske mindretals ledelse efter denne dato havde frasagt sig samarbejdet med Hitlertyskland og med den tyske besættelsesmagt, var ledelsen straks blevet arresteret, fængslet og sandsynligvis også skudt. Hertil indvendte Henrik Skov Kristensen, at mindretalsledelsen og mindretallet på mange måder forstærkede sin solidaritet med besættelsesmagten efter den 29. august 1943. Mange lod sig forst hverve efter denne dato, og f.eks. "Selbstschutz « blev forst oprettet i 1944.

Men der fandtes altså »et andet Tyskland « i det tyske mindretal under nazismen, understregede Siegfried Matlok. Han beklagede dog, at dette andet Tyskland efter 1945 havde været for svagt til at 
bane vejen for et opgør med fortiden. Når det tyske mindretal efter krigen havde haft svært ved at gennemfore en rigtig Vergangenheitsbewältigung, i stil med tyskerne syd for grænsen, hang det sammen med interneringerne, sagde han. Det sammenhold, der opstod i Fårhuslejren, blokerede for selvransagelsen. Siegfried Matlok fortsatte: »Vi har haft mange problemer i mindretallet - også efter 1945. En strid mellem dem, der stod for Haderslebener Kreis og selvfølgelig også den nye ledelse med Rudolf Stehr som generalsekretær og selvfølgelig også det, som her er blevet omtalt som Fårhus-myten.«

Siegfried Matlok var den eneste af paneldeltagerne, som foretog en sondring mellem det officielle nazistiske og det uofficielle demokratiske mindretal. Men eftersom det sidste var både meget lille og i sagens natur også usynligt før maj 1945, så kan det måske heller ikke undre, at den danske flertalsbefolkning ikke tog særligt hensyn til det, da opgørets time endelig kom.

\section{Fårhusmentaliteten og loyaliteten derefter}

Henrik Skov Kristensen gjorde et beslægtet emne til et hovedpunkt i sin overordnede vurdering af mindretallets forhold til retsopgøret. Han vurderede, at mindretallet havde undladt at forholde sig til, at det ikke blot var Tyskland, man solidariserede sig med under krigen, men også et forbryderisk regime og en totalitær ideologi. Interneringerne og den mentalitet, der opstod i Fårhuslejren, den såkaldte Fårhusmentalitet, havde blokeret for selvransagelsen og givet læ for en uforbeholden forkastelse af hele retsopgørets legitimitet. Henrik Skov Kristensen fortsatte: "I stedet har der været en tendens til at søge tilflugt $i$ en dobbelt offerrolle: først forført og udnyttet af det tyske Mutterland og siden svigtet af den danske herbergstat. Mindretallet har i efterkrigsårene aldrig villet anerkende retsopgøret. Tværtimod blev det i efterkrigsårene et politisk hovedmål at opnå 'retfærdighed' og rehabilitering for de dømte.«

Henrik Skov Kristensen pegede på, at mindretallet i tiden efter 1945 havde giort livet svært for sig selv, fordi det havde udsendt "tvetydige signaler « til det omgivende danske samfund - signaler, som svækkede den loyalitet, man fra december 1945 tilsagde den danske stat. Bund Deutscher Nordschleswiger havde i mange år været delt netop i spørgsmålet om forholdet til retsopgøret, sagde han. Langt op i 1960'erne måtte BDN's ledelse skræve over to fløje: de »de loyale« og 
»revisionisterne«. F.eks. havde Hans Schmidt-Gorsblock op til folketingsvalget i 1950 hvervet under parolen »troskab mod folk og hjemstavn ... væk med forbryderstemplet«. Også i Hans Schmidt-Oxbülls jomfrutale i Folketinget i 1953 havde kritikken af retsopgøret haft en central plads, mens man forgæves havde lyttet efter en afstandtagen til nazismen og samarbejdet med besættelsesmagten fra 1940-45, sagde Henrik Skov Kristensen.

Først i midten af 1960 'erne, da det tyske mindretal fik oprettet et kontaktudvalg under det danske statsministerium, blev retsopgørsproblematikken nedtonet, sagde Henrik Skov Kristensen. Men "trods nedtoningen er den hjemmetyske opfattelse af retsopgøret som uretfærdigt ikke lagt død. Opfattelsen findes nu hovedsagelig som en understrøm, der af og til kommer op til overfladen, « sagde han og gav en lang række eksempler på nyere erindringslitteratur, hvor Fårhusmentaliteten lever videre - litteratur, som bærer mindretallets blå stempel.

Henrik Skov Kristensen var den eneste af paneldeltagerne, der kom udførligt ind på Fårhusmentaliteten og dens negative indflydelse på mindretallets politiske linje.

Hans Schultz Hansen hæftede sig navnlig ved de kræfter i mindretallet, der fra begyndelsen af 1950'erne forsøgte at gøre op med fortiden og se fremad. Om Fårhusmentaliteten konkluderede Hans Schultz Hansen, at det havde det varet for længe, inden den var blevet overdøvet af andre og mere forsonlige toner. Fårhusmentaliteten og det manglende opgør med nazitidens forbrydelser fik lov til at præge billedet af det tyske mindretal, »og det har måske også bevirket, at det danske syn på retsopgøret har været mere stædigt end nødvendigt, " pointerede Hans Schultz Hansen. Ifølge hans mening havde mindretallet altså til en vis grad selv været skyld $i$, at fjendebilledet i Danmark fik lov til at stå længere, end godt var.

Günter Weitling mente, at det var urimeligt at beskylde BDN for at have forsømt at påtage sig et medansvar for den nazistiske periode. Han pegede $i$ den henseende på erklæringen om organisationens grundlæggelse i november 1945, der hvilede på "Haderslev-Erklæringen«. Begge erklæringer tog klart afstand fra den nazistiske fortid. De heri indeholdte udtalelser om BDN's demokratiske, humanistiske og kristne grundholdning og den absolutte loyalitet mod staten skulle forstås bagudrettet, sagde Günter Weitling, altså som en klar afstandtagen til fortidens linje. 
Günter Weitling henviste i øvrigt til den tyske forbundspræsident Richard von Weizsäckers besøg og den 5. maj 1985, hvor den daværende formand Gerhard Schmidt havde erklæret, at mindretallet havde taget ved lære af $\sin$ historie med det »nationalsocialistiske umenneskelige regime«. Efterfølgeren Hans Heinrich Hansen havde fortsat denne linje, ikke mindst ved genforeningsjubilæet den 11. juli 1995 på Dybbøl. Günter Weitling konkluderede: "Mindretallet har bekendt sig til sin historie og taget et medansvar for den mørke nazistiske periode. Man kan på denne baggrund ikke bebrejde BDN ikke at have ført klar tale vedrørende perioden 1933-45. Vedrørende retsopgøret er der vist tilbageholdenhed, og organisationen har bestemt ikke været den negative og aggressive Fårhusmentalitets advokat. BDN har efter min bedste overbevisning på pragmatisk vis formået at gennemføre en spagat mellem »ubetinget loyalitet " og nogle hjemmetyske kredses aversioner mod princippet tilbagevirkende kraft.«

\section{Undskyldning eller ej?}

Selvom anledningen til arrangementet var undervisningsminister Bertel Haarders udtalelse om, at man på dansk side burde erkende, at der var blevet begået uret mod medlemmer af det tyske mindretal, var det ikke alle paneldeltagere, der forholdt sig til direkte til spørgsmålet om en eventuel undskyldning.

Henrik Skov Kristensen gjorde. Han var grundlæggende uenig i mindretallets argument om, at dets samarbejde med den tyske besættelsesmagt blev undskyldt af, at danskerne også samarbejdede med tyskerne. Han sagde: "Nok var samarbejdspolitikken ikke heroisk, men den efterhånden fremherskende opfattelse, at Danmark og den store del af danskerne frivilligt og entusiastisk kollaborerede med den tyske besættelsesmagt, er lige så fjern fra virkeligheden som den tidligere forestilling om at danskerne alle med våben i hånd bekæmpede besættelsesmagten lige fra den 9. april 1940. Det er efter min mening direkte misvisende at gøre det tyske mindretals kollaboration med besættelsesmagten til ét fedt med regeringens og den brede befolknings tilpasning overfor besættelsesmagten."

Henrik Skov Kristensen sluttede med at konkludere, at Danmark under de givne omstændigheder godt kunne være retsopgøret med det tyske mindretal bekendt - også selv om der kan påvises urimeligheder $\mathrm{i}$ enkelte forhold. Han forsatte: »Der er efter min mening 
ikke grundlag eller behov for officielle undskyldninger, sådan som det har været på tale. Der er derimod behov for at lægge tingene frem og diskutere dem så åbent, nøgternt og fordomsfrit, som vi nu kan.»

Hverken Günter Weitling eller Siegfried Matlok forholdt sig så konkret til spørgsmålet om en dansk undskyldning. Men Günter Weitling pegede i stedet på, at man tilsyneladende havde glemt rehabiliteringsloven af 1950, som blandt andet kom 2000 medlemmer af mindretallet til gode. Günter Weitling gjorde desuden opmærksom på, at statsminister Hans Hedtoft havde gentaget denne rehabilitering i 1953 fra Folketingets talerstol i et svar til den hjemmetyske folketingsmand Hans Schmidt-Oxbüll. Her havde statsministeren sagt, at rehabiliteringen af de frontfrivillige var blevet afgjort med loven af 1950, der ligestillede de frivillige med uplettede danske statsborgere.

Günter Weitling undrede sig over, at disse udtalelser havde fået meget beskeden opmærksomhed, både i samtiden og senere hen. Han spurgte: »Hvorfor kom der hverken på dansk eller tysk side noget ud af disse tilkendegivelser? Der blev kun skænket dem lidt opmærksomhed. Endnu for få måneder siden blev det af direkte berørte hævdet, at de intet kendte til udtalelserne! «

Günter Weitling tolkede i øvrigt Bertel Haarders udtalelse således, at undskyldningen først og fremmest skulle gælde de folk, der i dagene umiddelbart efter 5 . maj i den såkaldte lovløse tid var blevet pågrebet, kun fordi de tilhørte det tyske mindretal. I oktober 1945 blev der vedtaget en lov, der skulle sikre disse folk rehabilitering og erstatning. I Senderjylland kom loven dog kun 14 personer til gode, oplyste Günter Weitling.

Siegfried Matlok udtalte sig hverken for eller imod en officiel dansk undskyldning. Men han glædede sig over, at Bertel Haarder havde bragt sagen på bane. Det, som der var brug for, var ikke en kollektiv frifindelse, men en nøgtern udredning af, hvor der var blevet begået uret. Siegfried Matloks indlæg var det sidste panelindlæg, inden ordet blev givet frit til tilhørerne.

Hen imod slutningen spørgerunden tog pastor Ove Hansen fra Kiel ordet. Han var årgang 1941. Han havde tidligere tilhørt det tyske mindretal i Aabenraa, men var rejst til Kiel som et led i sit personlige opgør med fortiden. Ove Hansens bemærkninger gjorde tilsyneladende dybt indtryk på tilhørerne, både danske og tyske. Selvom debatarrangementet ikke førte til et fælles dansk-tysk syn på historien, var Ove Hansens indlæg fra tilhørerpladserne måske i virkeligheden det 
tætteste, man kom på et fælles fodslag. Da han var færdig med at tale, høstede han i hvert fald aftenens største bifald.

Han sagde: "Min generation - min far har været i Waffen SS - vi har haft den store vanskelighed, at vore fædre og vore onkler ikke har talt med os. Der var en tavshed hele tiden. Jeg tror, det er svært at forestille sig, hvordan denne tavshed har bestemt vores liv. Det er vigtigt, at vi får talt ud om disse ting, for jeg mærker, at mange mennesker er meget mærkede af den tid. Der findes mange traumer. Vi må uden frygt beskæftige os med spørgsmålet om skyld. Jeg har oplevet, at man i dag kan tale med venner om det, men i min skoletid i slutningen af 1940 'erne og i 1950'erne var det ikke muligt. Det er en tung arv, vi bærer rundt på.« 